\title{
Probiotic attributes of Lactobacillus strains isolated from food and of human origin
}

\author{
Sandeep B. Gaudana, Akhilesh S. Dhanani and Tamishraha Bagchi* \\ Department of Microbiology and Biotechnology Centre, Faculty of Science, The M. S. University of Baroda, Vadodara, Gujarat \\ 390 002, India
}

(Received 26 May 2009 - Revised 19 November 2009 - Accepted 3 December 2009 - First published online 14 January 2010)

\begin{abstract}
Lactobacilli isolated from various sources were identified on the basis of $16 \mathrm{~S}-23 \mathrm{~S}$ rRNA gene intergenic region amplification and subsequent sequencing of the smaller intergenic region. An in vitro analysis of probiotic properties including binding, ability to tolerate different concentrations of bile, survival in acidic buffer and antimicrobial activity of four different isolates and two standard strains (Lactobacillus plantarum American Type Culture Collection (ATCC) 8014 and L. rhamnosus GG (LGG)) was carried out. The ability of each isolate to stimulate Caco-2 cells, human peripheral blood mononuclear cells (PBMC) and THP-1 cells resulting in immunomodulation of these cells was analysed. Isolates L. rhamnosus CS25 and L. delbrueckii M and standard strain ATCC 8014 showed broad antimicrobial activity, and isolates CS25 (percentage of survival $6.9 \%$ at $\mathrm{pH} 2.5,5.1 \%$ at $\mathrm{pH} 2.0$ ) and L. plantarum $\mathrm{CS} 23(5.7 \%$ at $\mathrm{pH} 2.5,4.9 \%$ at $\mathrm{pH} 2.0$ ) have shown good tolerance to acidic $\mathrm{pH}$. Isolate CS23 showed a good survival (14\%) after $2 \mathrm{~h}$ incubation in de Man, Rogosa and Sharpe (MRS) medium containing $3 \%$ bile salts. Isolates CS23, CS25 and L. fermentum ASt1 could stimulate Caco-2 cells, human PBMC and THP-1 cells for a strong and varied immunomodulatory response in these cells. Though LGG showed poor antimicrobial activity as well as bile and acid tolerance, it was found to be the best binding strain tested. Child faecal isolate CS23 from the present study showed high binding ability (seventeen bacteria/Caco-2), high tolerance to acidic $\mathrm{pH}$ and bile salts and significant immunomodulation; therefore it is a good potential probiotic candidate.
\end{abstract}

Adhesion: Immunomodulation: Indian Lactobacillus isolates: Probiotics

The human body contains diverse groups of commensal microbiota including both aerobes and anaerobes. The largest population of these resides in the gastrointestinal tract which is colonised by more than 400 bacterial species in the adult ${ }^{(1,2)}$. The commensal bacteria regulate intestinal epithelial development and function and any interruption of these interactions may result in disease conditions ${ }^{(3,4)}$. The beneficial effects of the gut microbiota are attributed to probiotics which are defined as 'Live micro-organisms that when administered in adequate amounts confer a health benefit on the host' ${ }^{(5)}$.

Lactobacillus species are Gram-positive, non-pathogenic and desirable members of the intestinal tract. The healthpromoting effects of lactobacilli have been widely explored and include stabilisation of the indigenous microbial population, protection against intestinal infection, alleviation of lactose intolerance, increased nutritional value of foods, reduction of serum cholesterol levels and non-specific enhancement of the immune systems ${ }^{(6-9)}$. Several lactobacilli which act as probiotic bacteria are currently being explored as novel biological therapeutic agents ${ }^{(10,11)}$. Since not all lactobacilli possess the ability to confer health benefits to the host, it becomes necessary to screen and characterise numerous strains in order to obtain ideal probiotics. The colonisation of the gastrointestinal tract is desirable for any probiotic which depends on several factors including the ability of the bacteria to tolerate acidic $\mathrm{pH}$ of the stomach and bile and on the adhesion of bacteria to intestinal cells and mucus ${ }^{(12)}$. Isolation from human hosts, the capability to tolerate acidic $\mathrm{pH}$ and bile, antimicrobial activity and a good adhesion ability are principle desirable properties in potential probiotics ${ }^{(13)}$. Several probiotic effects are mediated through immune regulation, particularly through establishing and maintaining a balance between pro- and anti-inflammatory cytokines ${ }^{(4,14,15)}$. This is why the study of immunomodulatory properties of probiotics also has a high priority. The human intestinal epithelial cell line Caco-2 has been extensively used to study the adhesion ability of lactobacilli ${ }^{(16,17)}$. This is primarily because Caco-2 cells express morphological and functional differentiation of mature enterocytes including polarisation and functional brush border in vitro ${ }^{(18)}$.

In the present study, the isolation of lactobacilli was carried out from food and human faecal samples with an aim to screen potential probiotic candidates for human use. The ability of the isolates to adhere to Caco- 2 monolayers, their capacity to tolerate bile salts and low $\mathrm{pH}$, and their antagonism against various organisms was tested. The antagonistic property was

\footnotetext{
Abbreviations: ATCC, American Type Culture Collection; cfu, colony-forming units; LGG, Lactobacillus rhamnosus GG; MRS, de Man, Rogosa and Sharpe; PBMC, peripheral blood mononuclear cells; RPMI, Roswell Park Memorial Institute.

* Corresponding author: Professor T. Bagchi, fax +91 265 2792508, email mailforbagchi@yahoo.com
} 
tested against five different pathogenic test cultures. The isolates were studied for their stimulation of Caco- 2 cells, THP-1 cells and human peripheral blood mononuclear cells (PBMC) through differences in the level of transcripts of selected cytokines and chemokine genes.

\section{Materials and methods \\ Isolation and identification of Lactobacillus}

Isolation was carried out from seven sources including one curd of buffalo milk, faeces from five breast-feeding human children aged 4-6 months and one human adult aged 27 years. About $1 \mathrm{~g}$ of faecal or curd sample was suspended in $10 \mathrm{ml}$ sterile normal saline, vigorously mixed and allowed to settle. A $100 \mu \mathrm{l}$ sample of the suspension was then spread on three Rogosa SL agar (a selective medium for Lactobacillus isolation; Himedia, Mumbai, India) ${ }^{(19)}$ plates containing cycloheximide (100 $\mu \mathrm{g} / \mathrm{ml}$; Sisco Research Laboratories, Mumbai, India) for each sample. The plates were incubated at $37^{\circ} \mathrm{C}$ until sufficient growth was observed. Between six and eight isolated colonies were then picked from each Rogosa SL agar plate and transferred to de Man, Rogosa and Sharpe (MRS; Himedia) agar plates and subjected to further microscopic and biochemical tests. Molecular identification of isolates was carried out by amplification of $16 \mathrm{~S}-23 \mathrm{~S}$ rRNA gene intergenic region as reported by Tannock et al. ${ }^{(20)}$. Briefly, $16 \mathrm{~S}-23 \mathrm{~S}$ rRNA gene intergenic regions of the isolates were amplified using primer 16-1A (5'-GAATCGCTAGTAATCG-3') and 23-1B (5'-GGGTTCCCCCATTCGGA-3 $3^{\prime}$ ) by colony $\mathrm{PCR}^{(20)}$. Amplification conditions were as follows: initial denaturation at $94^{\circ} \mathrm{C}$ for $5 \mathrm{~min}$, followed by thirty cycles of denaturation at $94^{\circ} \mathrm{C}$ for $45 \mathrm{~s}$, annealing for $30 \mathrm{~s}$ at $55^{\circ} \mathrm{C}$, followed by extension at $72^{\circ} \mathrm{C}$ for $1 \mathrm{~min}$ and a final extension at $72^{\circ} \mathrm{C}$ for $6 \mathrm{~min}$. The smaller band was excised, eluted and re-amplified using the same set of primers and the resultant amplicon was sequenced. The sequences were compared with the $16 \mathrm{~S}-23 \mathrm{~S}$ rRNA gene intergenic small spacer region sequences held in GenBank. The sequences of the $16 \mathrm{~S}-23 \mathrm{~S}$ rRNA gene intergenic region of the isolates are held in GenBank (for accession numbers, see Table 1). Standard strains Lactobacillus rhamnosus GG (LGG) and Lactobacillus plantarum American Type Culture Collection (ATCC) 8014 were obtained as kind gifts from Dr Shira Doron (MD, Department of Medicine, Tufts Medical Center, Boston, MA, USA) ${ }^{(21)}$ and Food and Drugs Laboratory (FDL; Vadodara, India), respectively.

\section{Cell culture}

The human colonic adenocarcinoma cell line Caco-2 and monocyte-like cell line THP-1 were obtained from the National Centre for Cell Science, Pune, India, which were routinely cultured in Dulbecco's modified Eagle's medium and Roswell Park Memorial Institute (RPMI)-1640 (Sigma-Aldrich, St Louis, MO, USA) medium, respectively, at $37^{\circ} \mathrm{C}$ in a humidified atmosphere containing $5 \% \mathrm{CO}_{2}-95 \%$ air atmosphere. The media were supplemented with $10 \%(\mathrm{v} / \mathrm{v})$ fetal bovine serum (Sigma-Aldrich), $10 \mathrm{~mm}$-non-essential amino acids, $1 \mathrm{~mm}$-sodium pyruvate and gentamicin $(50 \mu \mathrm{g} / \mathrm{ml})$. The media lacked gentamycin whenever antibiotic-free medium was used.

\section{Bile and $\mathrm{pH}$ tolerance}

The minimal inhibitory concentration of bile was determined for individual lactobacilli strains by inoculating $1 \times 10^{6}$ bacterial cells in MRS broth containing $1-5 \%(\mathrm{w} / \mathrm{v})$ bile salts (sodium cholate and sodium deoxycholate; Himedia) for $24 \mathrm{~h}$. Based on this subsequently, bacterial cells grown overnight in normal MRS broth were washed with PBS and $20 \mu \mathrm{l}$ each of selected lactobacilli $\left(1 \times 10^{8}\right.$ colony-forming units $(\mathrm{cfu}) / \mathrm{ml})$ were transferred to $980 \mu \mathrm{l}$ MRS broth containing $3 \%$ bile salts and incubated at $37^{\circ} \mathrm{C}$ for $2 \mathrm{~h}$. To examine the survival rate of different lactobacilli under acidic condition at $37^{\circ} \mathrm{C}, 20 \mu \mathrm{l}$ each of selected lactobacilli $\left(1 \times 10^{8} \mathrm{cfu} / \mathrm{ml}\right)$ were transferred to $980 \mu \mathrm{l}$ of acidic buffer (consisting of $3.5 \mathrm{~g}$ D-glucose, $2.05 \mathrm{~g} \mathrm{NaCl}, 0.6 \mathrm{~g} \mathrm{KH}_{2} \mathrm{PO}_{4}, 0.11 \mathrm{~g} \mathrm{CaCl}$ and $0.37 \mathrm{~g} \mathrm{KCl}$ per litre; the $\mathrm{pH}$ was adjusted to 2.0 and 2.5 using $\mathrm{HCl})^{(22)}$. For both bile and acid tolerance, the samples were taken at $0 \mathrm{~min}$ and $2 \mathrm{~h}$ and cultures were plated after appropriate dilution on MRS agar plate; enumeration was done following $48 \mathrm{~h}$ incubation at $37^{\circ} \mathrm{C}$.

\section{Adhesion assay}

For the adhesion assay, Caco- 2 cells were seeded at a density of $10^{4}$ cells per well in twenty-four-well standard tissue culture plates (Corning Inc., Corning, NY, USA) and maintained for 2 weeks following confluence. Before the adhesion assay, Caco-2 monolayers were pre-incubated with antibiotic-free medium for $4 \mathrm{~h}$. The $\mathrm{pH}$ of the media used for the adhesion assay was adjusted to 6.5 with $1 \mathrm{M}-\mathrm{HCl}$ before use. Lactobacilli cells were harvested by centrifugation $(10000 \mathrm{~g}$ for $2 \mathrm{~min}$ at $4^{\circ} \mathrm{C}$ ), washed twice with Dulbecco's PBS, pH 7.0 (Sigma-Aldrich) and cell density was adjusted to the desired level by measuring absorbance at $600 \mathrm{~nm}$. The exact number

Table 1. Identification of Lactobacillus isolates based on percentage similarity to $16 \mathrm{~S}-23 \mathrm{~S}$ rRNA small intergenic spacer region sequences with database in GenBank

\begin{tabular}{llll}
\hline Isolate & Source & $\begin{array}{c}\text { GenBank accession no. of } \\
16 S-23 S \text { sequence }\end{array}$ & $\begin{array}{c}\text { Similarity of 16S-23S sequence to that } \\
\text { of reference strain in } \\
\text { GenBank (\%) }\end{array}$ \\
\hline M & Curd of buffalo milk & FJ899641 & Lactobacillus delbrueckii \\
ASt1 & Faeces of adult human & FJ899642 & Lactobacillus fermentum \\
CS23 & Faeces of human child & FJ899639 & Lactobacillus plantarum \\
CS25 & Faeces of human child & FJ899640 & Lactobacillus rhamnosus \\
\hline
\end{tabular}


of viable lactobacilli used in the assays was determined for each experiment by plate counting on MRS agar. Wells with Caco-2 monolayers were inoculated with $1 \times 10^{8}$ viable cells of each bacterial cell suspension and incubated at $37^{\circ} \mathrm{C}$ for $90 \mathrm{~min}$ in $5 \% \mathrm{CO}_{2}-95 \%$ air atmosphere. Un-adhered bacterial cells were then withdrawn from the wells and the Caco-2 monolayers were washed twice with $1 \mathrm{ml}$ PBS each. The Caco- 2 cells were lysed by treatment with $0.5 \mathrm{ml}$ $0.05 \%$ (v/v) Triton X-100 in PBS for $20 \mathrm{~min}$ at $37^{\circ} \mathrm{C}$. The Caco-2 lysate including bound lactobacilli was plated after appropriate dilution on MRS agar plate; enumeration was done following $48 \mathrm{~h}$ incubation at $37^{\circ} \mathrm{C}$. It was also determined that a 30 min treatment of $0.05 \%(v / v)$ Triton X-100 in PBS at $37^{\circ} \mathrm{C}$ did not affect the viability of lactobacilli (data not shown). At the end of each experiment, three randomly preselected unused wells were trypsinised and numbers of Caco- 2 cells were counted on a haemocytometer. The average value of the Caco-2 cell count was used for expressing the adhered bacteria per Caco- 2 cell.

\section{Antimicrobial activity}

The antimicrobial activity of lactobacilli was determined by the agar spot test as described by Schillinger \& Lücke $^{(23)}$ with minor modifications. Briefly, $5 \mu \mathrm{l}$ each of selected Lactobacillus strains $\left(1 \times 10^{8} \mathrm{cfu} / \mathrm{ml}\right)$ was spotted on the surface of an MRS agar plate and incubated for $24 \mathrm{~h}$ at $37^{\circ} \mathrm{C}$ for the spots to develop. A $150 \mu \mathrm{l}$ sample of each of the indicator bacteria (listed in Table 2) grown overnight in Luria broth under shaking condition at $37^{\circ} \mathrm{C}$ was vigorously mixed with $15 \mathrm{ml}$ of Luria soft agar $(0.6 \%$ agar, w/v) and poured over the MRS agar plates containing developed colonies of lactobacilli. The plates were then incubated for $24 \mathrm{~h}$ at $37^{\circ} \mathrm{C}$ and the zones of inhibition were measured and expressed as described by Baccigalupi et al. ${ }^{(24)}$. The test strains used were Shigella dysentery, Staphylococcus aureus (ATCC 6538), Pseudomonas aeruginosa (ATCC 25668),
Salmonella typhi and Escherichia coli S5, obtained from the culture collection facility at our department.

\section{Stimulation of Caco-2 monolayers with lactobacilli}

To obtain monolayers, $5 \times 10^{4}$ Caco- 2 cells were seeded in a T25 tissue culture flask (Corning Incorporated) and maintained for 2 weeks post-confluence under the same conditions as described above. The Caco- 2 monolayers were stimulated with $1 \times 10^{8} \mathrm{cfu} / \mathrm{ml}^{(25)}$ of different lactobacilli and co-incubated for $90 \mathrm{~min}$ in the absence of gentamycin at $37^{\circ} \mathrm{C}$ in a $\mathrm{CO}_{2}$ incubator. Thereafter, gentamycin $(50 \mu \mathrm{g} / \mathrm{ml})$ was added to prevent bacterial growth and further incubated under the same conditions for another $4 \mathrm{~h}$ and $30 \mathrm{~min}$. At the end of incubation, the culture supernatant fraction was discarded and Caco-2 monolayers were lysed in the presence of guanidine thiocyanate which is included in the total RNA extraction kit (Bangalore Genei, Bangalore, India) that was employed. Further steps were performed as per the manufacturer's instructions.

\section{Isolation of human peripheral blood mononuclear cells}

PBMC were separated as described previously ${ }^{(26)}$. Briefly, $20 \mathrm{ml}$ of peripheral blood was collected in EDTA-coated vials (Himedia) from two healthy donors. The present study was conducted according to the guidelines laid down in the Declaration of Helsinki and all procedures involving human subjects were approved by the Institutional Ethics Committee for Human Research of the Faculty of Science, M. S. University of Baroda. Written informed consent was obtained from all subjects. The samples were layered over an equal volume of Histopaque-1077 (Sigma-Aldrich) and centrifuged for $20 \mathrm{~min}$ at $400 \mathrm{~g}$ at room temperature. The mononuclear cell layer was carefully pipetted out from each donor, mixed and washed twice with $10 \mathrm{ml}$ PBS each. Pellets were then re-suspended in $7 \mathrm{ml}$ RPMI-1640 cell culture medium.

Table 2. Concentration and survival rate of Lactobacillus strains under acidic conditions and in the presence of $3 \%$ bile salts $\ddagger$ (Mean values and standard deviations and percentage survival rates)

\begin{tabular}{|c|c|c|c|c|c|c|c|c|c|c|c|c|}
\hline & & & & & & & \multicolumn{6}{|c|}{ Acid tolerance } \\
\hline & \multicolumn{3}{|c|}{ Pre-incubation } & \multicolumn{3}{|c|}{ Bile tolerance } & \multicolumn{3}{|c|}{$\mathrm{pH} 2.5$} & \multicolumn{3}{|c|}{$\mathrm{pH} 2.0$} \\
\hline & \multicolumn{2}{|c|}{$\begin{array}{l}\text { Lactobacillus } \\
\text { concentration } \\
\left(\log _{10} \mathrm{cfu} / \mathrm{ml}\right)\end{array}$} & \multirow[b]{2}{*}{$\begin{array}{c}\text { Survival rate } \\
(\%)\end{array}$} & \multicolumn{2}{|c|}{$\begin{array}{l}\text { Lactobacillus } \\
\text { concentration } \\
\left(\log _{10} \mathrm{cfu} / \mathrm{ml}\right)\end{array}$} & \multirow[b]{2}{*}{$\begin{array}{c}\text { Survival rate } \\
(\%)\end{array}$} & \multicolumn{2}{|c|}{$\begin{array}{l}\text { Lactobacillus } \\
\text { concentration } \\
\left(\log _{10} \mathrm{cfu} / \mathrm{ml}\right)\end{array}$} & \multirow[b]{2}{*}{$\begin{array}{c}\text { Survival rate } \\
(\%)\end{array}$} & \multicolumn{2}{|c|}{$\begin{array}{l}\text { Lactobacillus } \\
\text { concentration } \\
\left(\log _{10} \mathrm{cfu} / \mathrm{ml}\right)\end{array}$} & \multirow[b]{2}{*}{$\begin{array}{c}\text { Survival rate } \\
(\%)\end{array}$} \\
\hline & Mean & SD & & Mean & SD & & Mean & SD & & Mean & SD & \\
\hline LGG & 6.57 & 0.13 & 100 & $5 \cdot 30$ & 0.07 & $5 \cdot 34$ & 4.57 & 0.11 & $1 \cdot 0$ & 4.54 & 0.04 & 0.91 \\
\hline ATCC 8014 & 6.43 & 0.18 & 100 & $5 \cdot 04$ & 0.05 & $3 \cdot 88$ & $4 \cdot 34$ & 0.14 & 0.80 & 4.07 & 0.09 & 0.42 \\
\hline $\mathrm{M}$ & $6 \cdot 43$ & $0 \cdot 10$ & 100 & $5 \cdot 11$ & 0.10 & 4.83 & $5 \cdot 18^{\star} \dagger$ & 0.09 & $5 \cdot 40$ & $5 \cdot 07^{\star} \dagger$ & 0.06 & $4 \cdot 31$ \\
\hline ASt1 & 5.93 & 0.05 & 100 & $4 \cdot 85^{\star} t$ & 0.02 & $8 \cdot 27$ & $4.53^{\star} \dagger$ & 0.07 & 4.03 & $4 \cdot 29^{*} \dagger$ & 0.06 & $2 \cdot 33$ \\
\hline CS23 & $6 \cdot 18$ & 0.12 & 100 & $5 \cdot 34^{*} \dagger$ & 0.04 & 14.04 & $4.95^{\star} \dagger$ & 0.01 & $5 \cdot 70$ & $4 \cdot 88^{*} \dagger$ & 0.01 & 4.90 \\
\hline CS25 & $6 \cdot 19$ & 0.13 & 100 & $4 \cdot 98^{*}$ & 0.03 & 5.91 & $5 \cdot 05^{\star} \dagger$ & 0.02 & $6 \cdot 90$ & $4 \cdot 92^{*} \dagger$ & 0.01 & $5 \cdot 12$ \\
\hline
\end{tabular}

cfu, Colony-forming units; LGG, Lactobacillus rhamnosus GG; ATCC, American Type Culture Collection; ATCC 8014, L. plantarum ATCC 8014; M, L. delbrueckii M; ASt1, L. fermentum ASt1; CS23, L. plantarum CS23; CS25, L. rhamnosus CS25.

${ }^{*}$ Mean value of isolates was significantly higher than that of $L$. plantarum ATCC $8014(P<0.05)$.

† Mean value of isolates was significantly higher than that of $L$. rhamnosus $G G(P<0.05)$.

‡Results were obtained from three independent experiments. The strains were compared with two different controls (LGG and ATCC 8014) by means of two independent ANOVA tests. Significant ANOVA were followed by Dunnett's test for multiple comparisons $v$. the control group. 
Stimulation of peripheral blood mononuclear cells and THP-1 cells with lactobacilli

The cell number of PBMC and THP-1 cells for stimulation

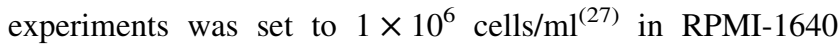
and $1 \mathrm{ml}$ each of cell suspension was transferred to a twenty-four-well plate. To this, $50 \mu \mathrm{l}$ of different lactobacilli suspensions containing $1 \times 10^{6}$ bacteria were added and co-incubated for $90 \mathrm{~min}$ in the absence of gentamycin at $37^{\circ} \mathrm{C}$ in a $\mathrm{CO}_{2}$ incubator. Thereafter, gentamycin $(50 \mu \mathrm{g} / \mathrm{ml})$ was added to prevent bacterial growth and further incubated under the same conditions for another $4 \mathrm{~h}$ and $30 \mathrm{~min}$. Cells from the suspension culture and adhered cells were harvested, pooled and subjected to total RNA extraction using the kit as mentioned above.

\section{RNA isolation and RT-PCR}

Total RNA was isolated from control (to which no bacteria were added) Caco- 2 cells, PBMC and THP-1 cells and those co-incubated with various lactobacilli and using a total RNA extraction kit (Bangalore Genei). The quality of the RNA samples was assessed by inspecting the $28 \mathrm{~S}$ and $18 \mathrm{~S}$ bands following agarose gel electrophoresis. A quantity of $2 \mu \mathrm{g}$ of each RNA sample was used with Oligo (dT18) for cDNA synthesis in a $20 \mu \mathrm{l}$ system using an M-MuLV RT-PCR kit (Bangalore Genei) following the manufacturer's instructions. Briefly, the RNA and Oligo (dT18) mixture was incubated at $65^{\circ} \mathrm{C}$ for $10 \mathrm{~min}$, centrifuged briefly and kept at room temperature for $2 \mathrm{~min}$. Into this RNAsin, dithiothreitol, RT buffer, deoxynucleotide triphosphate (dNTP) and M-MuLV RT were added, as instructed by the manufacturer and incubated further at $37^{\circ} \mathrm{C}$ for $1 \mathrm{~h}$, followed by $5 \mathrm{~min}$ incubation at $95^{\circ} \mathrm{C}$. Each of the cDNA preparations was then amplified for thirty cycles in a thermal cycler (Eppendorf, Hamburg, Germany) with $\beta$-actin-specific primers (forward, $5^{\prime}$-AGCGGGAAATCGTGCGTGACA-3'; reverse, 5'-CGCAACTAAGTCATAGTCCG-3', generating an amplicon of $536 \mathrm{bp}$ ) by taking $1 \mu \mathrm{l}$ of the cDNA in a $12.5 \mu \mathrm{l}$ system. This was used as a control for the synthesis of cDNA. Controls for checking genomic DNA contamination included amplification of the total RNA without reverse transcription which did not give any amplicon (results not shown). PCR amplifications were then performed with specific primers for cytokines in a $12.5 \mu \mathrm{l}$ system with $1 \mu \mathrm{l}$ of the first-strand cDNA, $0.2 \mathrm{~mm}$ deoxynucleotide triphosphates (dNTPs), $1.5 \mathrm{mM}-\mathrm{MgCl}_{2}$ and 1.25 pmol each of the forward and reverse primers. This was run for thirty cycles after the addition $0.5 \mathrm{U}$ of Taq polymerase. Amplification conditions were as follows: initial denaturation at $94^{\circ} \mathrm{C}$ for $5 \mathrm{~min}$, followed by thirty cycles of denaturation at $94^{\circ} \mathrm{C}$ for $45 \mathrm{~s}$, annealing for $30 \mathrm{~s}$ at $66^{\circ} \mathrm{C}$ for $\beta$-actin, $60^{\circ} \mathrm{C}$ for IL-6, IL-8, IL-12p35 and transforming growth factor- $\beta, 62^{\circ} \mathrm{C}$ for IL-12p40 and TNF- $\alpha$ and $56^{\circ} \mathrm{C}$ for IL-15 followed by extension at $72^{\circ} \mathrm{C}$ for $1 \mathrm{~min}$ and a final extension at $72^{\circ} \mathrm{C}$ for $6 \mathrm{~min}$. PCR products separated on a $2 \%$ agarose gel were stained with ethidium bromide $(0.5 \mu \mathrm{g} / \mathrm{ml})$, following which densitometric analysis was carried out using AlphaEaseFC 4.0 software (Alpha Innotech, San Leandro, CA, USA) and the results are expressed as integrated density value divided by the selected area of band on the gel.

\section{Statistics}

Values are given as mean values and standard deviations of triplicate independent experiments. Significant ANOVA were followed by the Dunnett test in the case of the adhesion assay and immunomodulation by different lactobacilli for Caco-2 cells, human PBMC and THP-1 cells with respect to the respective controls $(P<0 \cdot 05)$. All analysis was conducted using SigmaStat 3.5 software (Cranes Software International, Bangalore, India).

\section{Results and discussion}

\section{Isolation and identification of Lactobacillus}

Out of 143 isolates screened, twenty-seven isolates which were Gram-positive rods, found negative for the presence of endospore and for the production of catalase, and which could grow on Rogosa SL and MRS agar plates were selected for subsequent molecular identification on the basis of $16 \mathrm{~S}-23 \mathrm{~S}$ rRNA gene intergenic region amplification. The agarose gel mobility of the amplification products generated from the 16S-23S rRNA gene intergenic region of eighteen isolates matched with that of standard strains LGG and ATCC 8014. The smaller intergenic region of ten of these eighteen isolates was sequenced. In addition, the smaller intergenic region of three of nine others whose amplified product size was distinct from that of standard strains was sequenced and following sequence alignment with the National Center for Biotechnology Information (NCBI) database only the former ten were found to belong to the Lactobacillus genus. Of these, L. plantarum CS23, L. rhamnosus CS25, L. fermentum ASt1 and L. delbrueckii $\mathrm{M}$ were used in the present study. The 16S-23S rRNA gene intergenic region sequences of these strains are held in GenBank and their corresponding accession numbers are shown in Table 1. A potential probiotic organism is preferred to be of human origin ${ }^{(28,29)}$ so that it can lead us to a candidate probiotic eventually targeted for human consumption. Commercially available probiotic lactobacilli such as LGG, L. plantarum 299v and L. gasseri LA39 have all been of human origin, as they have been isolated from human faeces $^{(21,30,31)}$. The isolates have been assayed in vitro for significant probiotic properties such as the ability to adhere to Caco-2 monolayers, their tolerance to bile and an acidic environment, the degree of antagonism they exhibit against selected pathogenic organisms and the ability to modulate the immune response of human PBMC, Caco-2 and THP-1 cells.

\section{Bile and acid tolerance}

From different concentration of bile salts taken, $3 \%$ bile salts in MRS broth was the minimal inhibitory concentration of bile for most Lactobacillus strains (data not shown); hence the survival of lactobacilli post $2 \mathrm{~h}$ incubation in MRS containing $3 \%$ bile salts was analysed and the results were subjected to statistical analysis $(P<0 \cdot 05)$. As given in Table 2, isolate CS23 showed an excellent survival of $14.04 \%$ in contrast to standard strains LGG and ATCC 8014, which showed survival of 5.34 and $3.88 \%$, respectively. Survival rates of lactobacilli in acidic buffer ( $\mathrm{pH} 2.5$ and 2.0) were examined by the difference in viable cell counts following $0 \mathrm{~min}$ and $2 \mathrm{~h}$ incubation, as shown in Table 3. The isolate CS25 
Table 3. Spectrum of antimicrobial activity exhibited by various lactobacilli*

\begin{tabular}{|c|c|c|c|c|c|}
\hline & Shigella dysentery & $\begin{array}{c}\text { Staphylococcus aureus } \\
\text { ATCC } 6538\end{array}$ & $\begin{array}{c}\text { Pseudomonas aeruginosa } \\
\text { ATCC } 5668\end{array}$ & Salmonella typhi & Escherichia coli S5 \\
\hline LGG & ++ & + & + & +++ & +++ \\
\hline ATCC 8014 & +++ & ++ & ++ & +++ & +++ \\
\hline M & ++ & ++ & ++ & +++ & +++ \\
\hline ASt1 & +++ & + & $+1-$ & +++ & +++ \\
\hline CS23 & +++ & ++ & $+1-$ & +++ & +++ \\
\hline CS25 & +++ & ++ & ++ & +++ & +++ \\
\hline
\end{tabular}

ATCC, American Type Culture Collection; LGG, Lactobacillus rhamnosus GG; ATCC 8014, L. plantarum ATCC 8014; M, L. delbrueckii M; ASt1, L. fermentum ASt1; CS23, L. plantarum CS23; CS25, L. rhamnosus CS25.

* The inhibition zones $1 \mathrm{~mm}, 2 \mathrm{~mm}, 2-5 \mathrm{~mm}$ and more than $5 \mathrm{~mm}$ were classified as strains of no $(+/-)$, mild $(+)$, strong $(++)$ and very strong $(+++)$ inhibition, respectively.

$(6.90 \%$ at $\mathrm{pH} 2.5,5.12 \%$ at $\mathrm{pH} 2.0)$ showed the highest survival in acidic $\mathrm{pH}$, immediately followed by $\mathrm{CS} 23, \mathrm{M}$

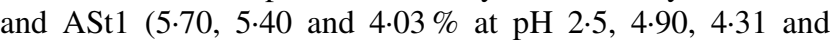
$2.33 \%$ at $\mathrm{pH} 2 \cdot 0$, respectively). Before the lactobacilli reach the hindgut region where they are generally known to colonise in human hosts, the organism needs to survive through acidic $\mathrm{pH}$ and bile. So the tolerance of an organism to these factors is equally important in selecting a potential probiotic. In studies by other authors, the survival of Lactobacillus isolates in $\mathrm{pH}$ 2.5 yielded similar results; however, the survival has not been more than $0.2 \%^{(32,33)}$.

\section{Adhesion assay}

In the present study none of the isolates showed better binding to Caco-2 than LGG (Fig. 1). One of our isolates, CS23, showed statistically significant better and another two, L. rhamnosus $\mathrm{CS} 25$ and $L$. delbrueckii $\mathrm{M}$, showed binding ability as good as L. plantarum ATCC 8014. The adult stool isolate ASt1 showed the poorest binding capacity. The same results were obtained when considering the percentage of the number of bacteria bound to the number of bacteria added per well (data not shown). Caco-2 cells have been widely accepted as an in vitro model for assessing the adhesion of potential probiotics, correlating with adherence

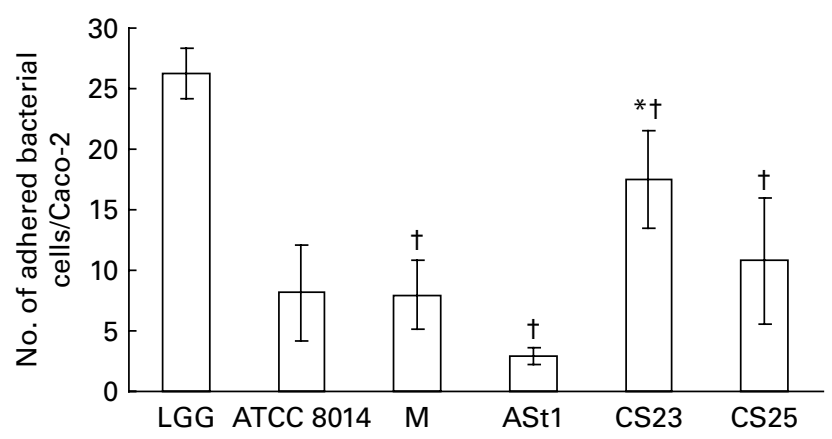

Fig. 1. Adhesion of Lactobacillus isolates to Caco-2 epithelial cell line compared with standard strains Lactobacillus rhamnosus GG (LGG) and L. plantarum American Type Culture Collection (ATCC) 8014 (ATCC 8014). M, L. delbrueckii M; ASt1, L. fermentum ASt1; CS23, L. plantarum CS23; CS25, L. rhamnosus CS25. Values are means of three independent experiments, with standard deviations represented by vertical bars. The strains were compared with two different controls (LGG and ATCC 8014) by means of two independent ANOVA tests. Significant ANOVA were followed by Dunnett's test for multiple comparisons $v$. the control group. * Mean value of isolates was significantly different than that of ATCC $8014(P<0.05)$. † Mean value of isolates was significantly different than that of LGG $(P<0.05)$. to the intestinal epithelium in vivo. This is principally because Caco-2 cells express morphological and functional differentiation in vitro and express several markers that are distinctive of normal small-intestinal villi ${ }^{(16)}$. The ability of a probiotic to adhere to intestinal epithelium enables the organism to colonise the gut as it can resist against being washed out due to peristaltic and other movements inside the gut. Buck et al. ${ }^{(34)}$ reported a significant decrease in the adhesion ability of different isogenic surface protein mutants of L. acidophilus NCFM, thereby suggesting multiple cell-surface proteins imparting the organisms with the ability of binding to intestinal epithelial cells in vitro. Since the percentage of adhesion of a probiotic under a given set of conditions does not represent an absolute value, the adhesion should be represented as a value relative to a type $\operatorname{strain}^{(34,35)}$.

\section{Antimicrobial test}

As shown in Table 3, the antagonistic activity of the lactobacilli was examined against Gram-negative Shigella dysentery, $P$. aeruginosa, E. coli S5 and Salmonella typhi, as well as Gram-positive Staphylococcus aureus.

The isolate CS25 and standard strain ATCC 8014 had the highest inhibitory activity against both Gram-positive and Gram-negative bacteria, followed by $\mathrm{M}$ and CS23. All the strains tested showed a strong inhibition towards E. coli S5. Baccigalupi et al. had observed a range of antimicrobial responses by lactobacilli to various indicator bacteria and also indicated a strong possibility that these activities were not caused by an acidic environment ${ }^{(24)}$. In the present study, though CS23 and ATCC 8014 and similarly LGG and CS25 are from the same species, respectively, the difference in their antimicrobial activity suggests that antimicrobial attributes must be strain specific. Once colonised, the probiotics get an opportunity to exhibit their antimicrobial and immunomodulatory properties in favour of the host organism. The antimicrobial activity of Lactobacillus is generally due to production of lactic acid, $\mathrm{H}_{2} \mathrm{O}_{2}$ and/or other antibacterial molecules such as bacteriocin ${ }^{(36,37)}$. It should be interesting to study the mode of antimicrobial activity in different strains.

\section{Stimulation of Caco-2, human peripheral blood mononuclear cells and THP-1 co-cultured with lactobacilli}

The interaction of the enterocytes with micro-organisms is known to modulate the cytokine profile of the former. Certain cytokines in turn serve as chemo-attractants and activators of 

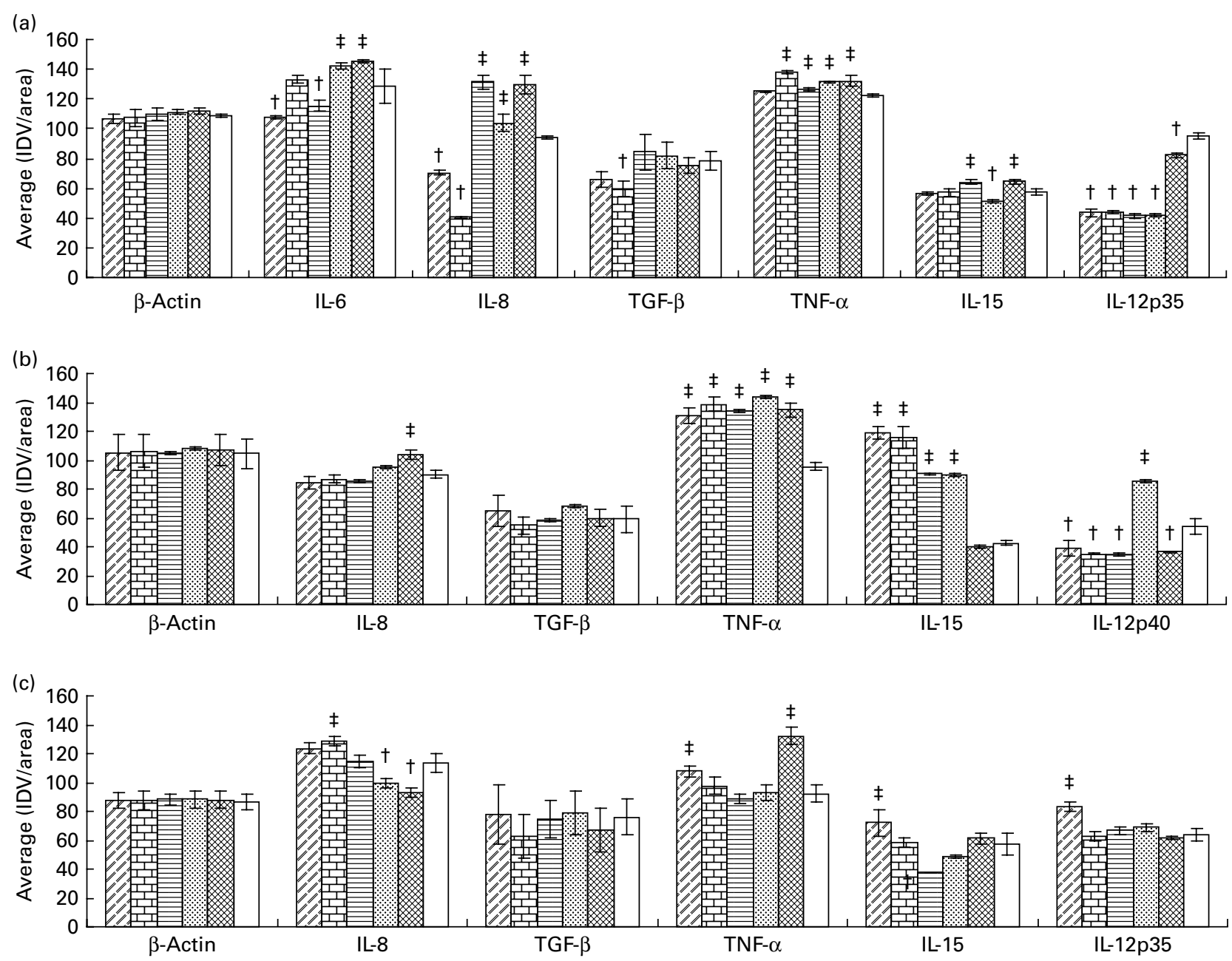

Fig. 2. Cytokines and chemokine transcript levels in (a) Caco- 2 cells co-incubated with different lactobacilli $\left(1 \times 10^{8}\right.$ colony-forming units (cfu)/ml), (b) peripheral blood mononuclear cells (PBMC) and (c) THP-1 cells co-incubated with different lactobacilli $\left(1 \times 10^{6}\right.$ cfu/ml). Different lactobacilli used in the study were:

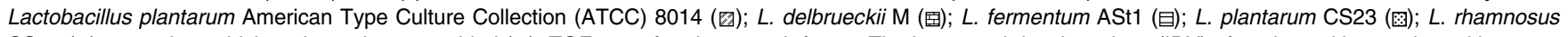
CS25 ( $\otimes$ ); control, to which no bacteria were added ( $\square$ ). TGF, transforming growth factor. The integrated density values (IDV) of each cytokine or chemokine were used to express its transcript levels. Values are means, with standard deviations represented by vertical bars. Significant ANOVA were followed by Dunnett's test for multiple comparisons $v$. the control group. †Within each cytokine or chemokine, mean value was significantly lower than that of the control $(P<0.05)$. $¥$ Within each cytokine or chemokine, mean value was significantly higher than that of the control $(P<0.05)$. No amplification products were observed for IL-12p40 in Caco-2 cells, IL-6 and IL-12p35 in PBMC and IL-6 and IL-12p40 in THP-1 cells.

other immunocompetent cells. The stimuli eventually have a potential to bring the immunocompetent cells from the gut-associated lymphoid population in direct contact with the intestinal microbiota, at least at the sites of injury. The bacteria, on the other hand, do have the potential to cross the epithelial barrier and thereafter come across gut-associated immune cells ${ }^{(38)}$. So, it becomes important to study the interaction of probiotics with the enterocytes as well as the other immunocompetent cells of the intestinal epithelium ${ }^{(28)}$. In the present study Caco-2 cells, THP-1 cells and the PBMC isolated from healthy human subjects have been used as in vitro models for studying the immunomodulatory capacity of different lactobacilli.

The presence of transcripts of $\beta$-actin (control) and a selected number of cytokine genes in Caco- 2 cells, human PBMC and THP-1 cells co-cultured with different lactobacilli was analysed employing semi-quantitative RT-PCR. They were compared with the control where none of the bacterial culture was added (Fig. 2). TNF- $\alpha$ and IL-6 are pro-inflammatory cytokines, which are produced by the host in response to bacterial colonisation or invasion and hence are central to the host defence mechanism against pathogens ${ }^{(25,39)}$. Though lipopolysaccharide of Gram-negative bacteria is known to stimulate their production, Miettinen et al. have reported an increase in IL-6 and TNF- $\alpha$ production in human PBMC exposed to lactobacilli and thereby suggested the use of probiotics as vaccine vectors and for the purpose of stimulating non-specific immunity ${ }^{(27)}$. In the present study, all the isolates have exhibited their ability to induce in Caco-2, and PBMC, a higher level of TNF- $\alpha$ transcript. In the case of THP-1, however, only ATCC 8014 and isolate CS25 had the capability to up-regulate TNF- $\alpha$ expression. Similarly, in the case of IL-6 and in Caco- 2 cells, isolates CS23 and CS25 had a strong up-regulatory potential compared with the down-regulation that is induced by ATCC 8014 and ASt1. Interestingly, there was no effect of these organisms on 
PBMC and THP-1 cells. It should be noted here that IL-6 is known to have both pro- as well as anti-inflammatory properties. It has a very important role in resolving the initial inflammatory reaction which leads to the activation of the adaptive immune response. Therefore, it appears that while CS23 and CS25 have the capacity to induce a strong pro-inflammatory environment, the presence of IL-6 may help them to convert an innate response to a more specific and sustained adaptive response against pathogens.

As is evident from the data, this possibility is strengthened all the more by the induction ability of both CS23 and CS25 towards the production by Caco- 2 of IL-8, a chemokine that is responsible for recruiting elements of the innate immune system. Of all the organisms tested for effect on IL-8 transcript levels, isolate CS25 has a stronger up-regulatory potential in Caco- 2 cells and PBMC, while ASt1 and M showed up-regulation in Caco-2 and THP-1, respectively. The other combinations of organism and cell lines tested are either neutral, or down-regulatory as in ATCC 8014 and isolate M for Caco-2, and isolates CS23 and CS25 for THP-1. IL-8 has an important role in the induction of neutrophil accumulation and activation ${ }^{(40)}$. Zhang et al. have suggested that a higher dose of LGG $\left(10^{7} \mathrm{cfu} / \mathrm{ml}\right)$ induces an increased production of IL-8 in Caco- $2^{(41)}$, which is in agreement with the present results wherein an increased transcription of IL- 8 has been seen in Caco-2 stimulated by ASt1, CS25 and CS23, and in PBMC stimulated by CS25, and THP-1 stimulated by M. The number of bacterial cells taken in the present study is $10^{8} \mathrm{cfu} / \mathrm{ml}$ with Caco- 2 and $10^{6} \mathrm{cfu} / \mathrm{ml}$ in studies with PBMC and THP-1. In spite of the high bacterial dose, a significant suppression of IL-8 transcription has been observed in Caco- 2 co-incubated with $\mathrm{M}$ and ATCC 8014 and in THP-1 co-incubated with CS25 and CS23. A high expression level of IL-8 is associated with the pathogenesis of several diseases including neonatal necrotising enterocolitis and so the immunosuppressive effects of the above isolates in context of IL- 8 transcription seem promising. However, further studies need to be conducted at the level of protein expression and in vivo.

IL-12 is a heterodimeric protein formed by a complex of p40 with $\mathrm{p} 35$, having an important role in interferon- $\gamma$ production by $\mathrm{T}$ helper cells ${ }^{(42)}$. The cytokine is thus nonfunctional in the absence of either subunit. All isolates and standard strains demonstrated suppression of IL-12p35 in Caco-2 and IL-12p40 was suppressed in PBMC by M, ASt1, CS25 and ATCC 8014. Isolate CS23 in PBMC and ATCC 8014 in THP-1 cells induced higher transcription of IL-12p40 and IL-12p35, respectively. IL-12 is a proinflammatory cytokine and plays an important role in the pathogenesis of inflammatory diseases such as Crohn's disease. In recent clinical trials the use of antibodies against IL-12 suggests a role for this cytokine in inflammatory bowel diseases $^{(43)}$ and hence the immunosuppressive property of the isolates in context of IL-12 can be appropriately utilised under similar circumstances.

IL-15 is a pleiotropic cytokine and regulates $\mathrm{T}$ cell and natural killer cell activation and proliferation ${ }^{(44)}$. It also has a role in maintaining immune homoeostasis in the mucosal environment by activating intraepithelial cells. It therefore appears from our data that ASt1 and CS25 are capable of functioning better at the mucosal interface. Interestingly, both of them exhibit either a neutral or down-regulatory potential when exposed to monocytes. Isolates ASt1 and CS25 in Caco-2, all strains (except CS25) in PBMC and ATCC 8014 in THP-1 have been observed to induce IL-15 at the transcripts level. IL-15 plays a critical role in the maintenance of memory lymphocytes by supporting proliferation. Another cytokine that has also been looked at, transforming growth factor- $\beta$, is an anti-inflammatory immunoregulatory cytokine which regulates the production of $\operatorname{IgA}$ antibodies and is important in early defence against intestinal infection ${ }^{(45)}$. In the present study, none of our isolates modulated significant mRNA expression of transforming growth factor- $\beta$, which is in support of earlier observations ${ }^{(46)}$.

Gabriella et al. have hypothesised that the intestinal epithelial cells which sense the bacterial surface with proinflammatory components such as EF-Tu (elongation factor thermo unstable) and GroEL and anti-inflammatory components, such as lipoteichoic acid, process the information and respond with a concurrent pro- or anti-inflammatory response $^{(47)}$. In the present study ASt1, CS23 and CS25 have shown strong and varied immunomodulatory characteristics that are reflected from the differences in the transcripts of different cytokines in Caco-2 cells, PBMC and THP-1 cells co-incubated with these strains as compared with the respective controls. Another point that comes across strongly from the present elaborate study is that each of these isolates is bestowed with its own combination of pro- and antiinflammatory potential. This gives rise to the possibility that each one of them may be useful under a specific set of immunological environments in the gut.

Though LGG has shown a very good binding capability in the present study as well as in several other studies ${ }^{(48,49)}$, our isolates have been able to score more in relation to other properties such as antimicrobial properties (CS25 and M), and bile and acid tolerance (CS23 and CS25). Jacobsen et al. ${ }^{(50)}$ had correlated the results of their in vitro assays for binding ability and acid tolerance with the in vivo performance of the strains and concluded that the survival of strains was strongly linked with adhesion ability to Caco-2 and tolerance to acidic $\mathrm{pH}$. The human child faecal isolate CS23 showed very good binding ability, high acid and bile tolerance and strong and varied immunomodulation, and is a promising contender for a potential probiotic strain.

\section{Acknowledgements}

The authors thank the Department of Biotechnology, New Delhi, India for financial support (grant no. BT/PR-7496/ PID/20/292/2006).

T. B. conceived of, conceptualised and supervised the present study. S. B. G. and A. S. D. performed the isolation, identification and analysis of probiotic properties. T. B. performed the cell culture. S. B. G. wrote the manuscript with A. S. D. and T. B. providing substantial contributions. All authors read and approved the findings of the study.

There is no conflict of interest to declare by any of the authors. 


\section{References}

1. Sghir A, Gramet G, Suau A, et al. (2000) Quantification of bacterial groups within human fecal flora by oligonucleotide probe hybridization. Appl Environ Microbiol 66, 2263-2266.

2. Falk PG, Hooper LV, Midtvedt T, et al. (1998) Creating and maintaining the gastrointestinal ecosystem: what we know and need to know from gnotobiology. Microbiol Mol Biol Rev 62, 1157-1170.

3. Guarner F \& Malagelada JR (2003) Gut flora in health and disease. Lancet 361, 512-519.

4. Isolauri E, Sutas Y, Kankaanpaa P, et al. (2001) Probiotics: effects on immunity. Am J Clin Nutr 73, 444S-450S.

5. Food and Agriculture Organization \& World Health Organization (2001) Health and Nutritional Properties of Probiotics in Food including Powder Milk with Live Lactic Acid Bacteria. Report of a Joint FAO/WHO Expert Consultation on Evaluation of Health and Nutritional Properties of Probiotics in Food Including Powder Milk with Live Lactic Acid Bacteria. http://www.who.int/foodsafety/publications/fs_management/en/ probiotics.pdf

6. Kim Y, Kim SH, Whang KY, et al. (2008) Inhibition of Escherichia coli $\mathrm{O} 157: \mathrm{H} 7$ attachment by interactions between lactic acid bacteria and intestinal epithelial cells. J Microbiol Biotechnol 18, 1278-1285.

7. Hooper LV, Xu J, Falk PG, et al. (1999) A molecular sensor that allows a gut commensal to control its nutrient foundation in a competitive ecosystem. Proc Natl Acad Sci U A 96, 9833-9838.

8. Perdigon G, Maldonado Galdeano C, Valdez JC, et al. (2002) Interaction of lactic acid bacteria with the gut immune system. Eur J Clin Nutr 56, Suppl. 4, S21-S26.

9. Suvarna VC \& Boby VU (2005) Probiotics in human health: a current assessment. Curr Sci 88, 1744-1748.

10. Sullivan A \& Nord CE (2005) Probiotics and gastrointestinal diseases. J Intern Med 257, 78-92.

11. Reid G, Kim SO \& Kohler GA (2006) Selecting, testing and understanding probiotic microorganisms. FEMS Immunol Med Microbiol 46, 149-157.

12. van Belkum A \& Nieuwenhuis EE (2007) Life in commercial probiotics. FEMS Immunol Med Microbiol 50, 281-283.

13. Dunne C, O'Mahony L, Murphy L, et al. (2001) In vitro selection criteria for probiotic bacteria of human origin: correlation with in vivo findings. Am J Clin Nutr 73, 386S-392S.

14. Gackowska L, Michalkiewicz J, Krotkiewski M, et al. (2006) Combined effect of different lactic acid bacteria strains on the mode of cytokines pattern expression in human peripheral blood mononuclear cells. J Physiol Pharmacol 57, Suppl. 9, 13-21.

15. Winkler P, Ghadimi D, Schrezenmeir J, et al. (2007) Molecular and cellular basis of microflora-host interactions. J Nutr 137, $756 \mathrm{~S}-772 \mathrm{~S}$

16. Coconnier MH, Klaenhammer TR, Kerneis S, et al. (1992) Protein-mediated adhesion of Lactobacillus acidophilus BG2FO4 on human enterocyte and mucus-secreting cell lines in culture. Appl Environ Microbiol 58, 2034-2039.

17. Tuomola EM \& Salminen SJ (1998) Adhesion of some probiotic and dairy Lactobacillus strains to Caco-2 cell cultures. Int J Food Microbiol 41, 45-51.

18. Sambuy Y, De Angelis I, Ranaldi G, et al. (2005) The Caco-2 cell line as a model of the intestinal barrier: influence of cell and culture-related factors on Caco-2 cell functional characteristics. Cell Biol Toxicol 21, 1-26.

19. Rogosa M, Mitchell JA \& Wiseman RF (1951) A selective medium for the isolation and enumeration of oral and fecal lactobacilli. J Bacteriol 62, 132-133.

20. Tannock GW, Tilsala-Timisjarvi A, Rodtong S, et al. (1999) Identification of Lactobacillus isolates from the gastrointestinal tract, silage, and yoghurt by $16 \mathrm{~S}-23 \mathrm{~S}$ rRNA gene intergenic spacer region sequence comparisons. Appl Environ Microbiol 65, 4264-4267.

21. Doron S, Snydman DR \& Gorbach SL (2005) Lactobacillus GG: bacteriology and clinical applications. Gastroenterol Clin North Am 34, 483-498, ix.

22. Casey PG, Casey GD, Gardiner GE, et al. (2004) Isolation and characterization of anti-Salmonella lactic acid bacteria from the porcine gastrointestinal tract. Lett Appl Microbiol 39, 431-438.

23. Schillinger U \& Lücke FK (1989) Antibacterial activity of Lactobacillus sake isolated from meat. Appl Environ Microbiol 55, 1901-1906.

24. Baccigalupi L, Di Donato A, Parlato M, et al. (2005) Small surface-associated factors mediate adhesion of a foodisolated strain of Lactobacillus fermentum to Caco-2 cells. Res Microbiol 156, 830-836.

25. Morita H, He F, Fuse T, et al. (2002) Adhesion of lactic acid bacteria to Caco-2 cells and their effect on cytokine secretion. Microbiol Immunol 46, 293-297.

26. Bam M \& Bagchi $\mathrm{T}$ (2009) Absence of tyrosinase-related protein-2/dopachrome tautomerase transcripts in PBMCs from vitiligo patients. Scand J Immunol 69, 366-373.

27. Miettinen M, Vuopio-Varkila J \& Varkila K (1996) Production of human tumor necrosis factor $\alpha$, interleukin-6, and interleukin-10 is induced by lactic acid bacteria. Infect Immun 64, 5403-5405.

28. Tannock GW (1997) Probiotic properties of lactic-acid bacteria: plenty of scope for fundamental R \& D. Trends Biotechnol 15, $270-274$.

29. Teitelbaum JE \& Walker WA (2002) Nutritional impact of pre- and probiotics as protective gastrointestinal organisms. Annu Rev Nutr 22, 107-138.

30. Goossens D, Jonkers D, Russel M, et al. (2005) Survival of the probiotic L. plantarum $299 \mathrm{v}$ and its effects on the faecal bacterial flora, with and without gastric acid inhibition. Dig Liver Dis 37, 44-50.

31. Kawai Y, Ishii Y, Uemura K, et al. (2001) Lactobacillus reuteri LA6 and Lactobacillus gasseri LA39 isolated from faeces of the same human infant produce identical cyclic bacteriocin. Food Microbiol 18, 407-415.

32. Kim PI, Jung MY, Chang YH, et al. (2007) Probiotic properties of Lactobacillus and Bifidobacterium strains isolated from porcine gastrointestinal tract. Appl Microbiol Biotechnol 74, $1103-1111$.

33. Perelmuter K, Fraga M \& Zunino P (2008) In vitro activity of potential probiotic Lactobacillus murinus isolated from the dog. J Appl Microbiol 104, 1718-1725.

34. Buck BL, Altermann E, Svingerud T, et al. (2005) Functional analysis of putative adhesion factors in Lactobacillus acidophilus NCFM. Appl Environ Microbiol 71, 8344-8351.

35. Blum S, Reniero R, Schiffrin EJ, et al. (1999) Adhesion studies for probiotics: need for validation and refinement. Trends Food Sci Technol 10, 405-410.

36. Kucerova K, Chumchalova J, Mikova K, et al. (2007) Screening of lactic acid bacteria for antimicrobial properties from mayonnaise-based products and raw materials. Eur Food Res Technol 226, 265-272.

37. Eschenbach DA, Davick PR, Williams BL, et al. (1989) Prevalence of hydrogen peroxide-producing Lactobacillus species in normal women and women with bacterial vaginosis. J Clin Microbiol 27, 251-256.

38. Perdigon G, Medina M, Vintini E, et al. (2000) Intestinal pathway of internalisation of lactic acid bacteria and gut mucosal immunostimulation. Int $J$ Immunopathol Pharmacol 13, $141-150$.

39. Solis-Pereyra B, Aattouri N \& Lemonnier D (1997) Role of food in the stimulation of cytokine production. Am J Clin Nutr 66, 521S-525S. 
40. Godaly G, Proudfoot AE, Offord RE, et al. (1997) Role of epithelial interleukin-8 (IL-8) and neutrophil IL-8 receptor A in Escherichia coli-induced transuroepithelial neutrophil migration. Infect Immun 65, 3451-3456.

41. Zhang L, Li N, Caicedo R, et al. (2005) Alive and dead Lactobacillus rhamnosus GG decrease tumor necrosis factor$\alpha$-induced interleukin- 8 production in Caco- 2 cells. J Nutr $\mathbf{1 3 5}$, $1752-1756$

42. Trinchieri G (2003) Interleukin-12 and the regulation of innate resistance and adaptive immunity. Nat Rev Immunol 3, 133-146.

43. Mannon PJ, Fuss IJ, Mayer L, et al. (2004) Anti-interleukin-12 antibody for active Crohn's disease. $N$ Engl J Med 351, 2069-2079.

44. Ma A, Boone DL \& Lodolce JP (2000) The pleiotropic functions of interleukin 15: not so interleukin 2-like after all J Exp Med 191, 753-756.

45. Sonoda E, Matsumoto R, Hitoshi Y, et al. (1989) Transforming growth factor $\beta$ induces IgA production and acts additively with interleukin 5 for IgA production. $J$ Exp Med 170, $1415-1420$.
46. Borruel N, Casellas F, Antolin M, et al. (2003) Effects of nonpathogenic bacteria on cytokine secretion by human intestinal mucosa. Am J Gastroenterol 98, 865-870.

47. Bergonzelli GE, Granato D, Pridmore RD, et al. (2006) GroEL of Lactobacillus johnsonii La1 (NCC 533) is cell surface associated: potential role in interactions with the host and the gastric pathogen Helicobacter pylori. Infect Immun 74, 425-434.

48. Matijasic BB, Narat M \& Zoric M (2003) Adhesion of two Lactobacillus gasseri probiotic strains on Caco-2 cells. Food Technol Biotechnol 41, 83-88.

49. Roselli M, Finamore A, Britti MS, et al. (2006) Probiotic bacteria Bifidobacterium animalis MB5 and Lactobacillus rhamnosus GG protect intestinal Caco-2 cells from the inflammation-associated response induced by enterotoxigenic Escherichia coli K88. Br J Nutr 95, 1177-1184.

50. Jacobsen CN, Rosenfeldt Nielsen V, Hayford AE, et al. (1999) Screening of probiotic activities of forty-seven strains of Lactobacillus spp. by in vitro techniques and evaluation of the colonization ability of five selected strains in humans. Appl Environ Microbiol 65, 4949-4956. 